\title{
Demethoxycurcumin inhibits cell proliferation, migration and invasion in prostate cancer cells
}

\author{
XIAOCHEN NI ${ }^{1}$, AILI ZHANG $^{1}$, ZHIHONG ZHAO $^{1}$, YONGQING SHEN $^{3}$ and SHIJIE WANG \\ Departments of ${ }^{1}$ Urology and ${ }^{2}$ Endoscopy, The Fourth Hospital, Hebei Medical University, \\ Hebei 050011; ${ }^{3}$ Hebei Medical University, Hebei 050017, P.R. China
}

Received January 11, 2012; Accepted February 22, 2012

DOI: $10.3892 /$ or.2012.1783

\begin{abstract}
Curcumin (CUR) is a natural agent that has been demonstrated to effectively inhibit prostate cancer growth. However, natural CUR is relatively unstable and can be easily degraded in vivo. Therefore, it is essential to develop other stable curcuminoids. Demethoxycurcumin (DMC) is a candidate that has been verified in several tumor types and has potential for the treatment of prostate cancer. In the present study, we investigated the effects of DMC on proliferation, apoptosis and migration of PC-3 cells. MTT assay results indicated that DMC inhibited PC-3 cell viability in a dose- and time-dependent manner, and DMC induced G2/M phase arrest. Furthermore, PC-3 cells in DMC-treated groups had a higher apoptotic rate compared with DMSO-treated control. This effect may be due to the activation of the caspase-3 pathway. In DMC-treated groups, migrating and invasive cells were dramatically reduced $(\mathrm{P}<0.05)$. The activity of MMP-2, which is correlated with migration and invasion was also suppressed by DMC. These results indicated that DMC may inhibit PC-3 cell migration and invasion partially by affecting MMP-2 activity. In conclusion, DMC significantly inhibits proliferation, migration and invasion of cultured PC-3 cells, and this study may provide evidence for future in vivo studies and clinical use.
\end{abstract}

\section{Introduction}

Prostate cancer is a common urologic malignant tumor, which is threatening more and more people currently. The emerging studies on cancer prevention and treatment with natural products expand the traditional treatment of prostate cancer (1). Curcuminoids are phenolic coloring compounds that can be extracted from the rhizomes of Curcuma longa linn. Curcumin (CUR), a member of curcuminoids, has potent anti-tumor effects

Correspondence to: Professor Shijie Wang, Research Center, Department of Endoscopy, The Fourth Hospital, Hebei Medical University, Hebei 050011 P.R. China

E-mail: aer8850@hotmail.com

Key words: prostate cancer, curcuminoids, curcumin, demethoxycurcumin, apoptosis, proliferation, migration to prostate cancer (2-4) and several other cancers, such as breast (5) and colon cancer (6). However, CUR can be easily degraded both in vitro and in vivo $(7,8)$. The anti-tumor activity of CUR will be enormously reduced, and this instability property of CUR limits its clinical use in cancer treatment. It is feasible to develop new stable compounds that are structurally similar as CUR but without the loss of anti-tumor activity. Demethoxycurcumin (DMC), an analogue of CUR, is one of such compounds. In comparison with CUR, the structure of DMC lacks one methoxy group directly linking to the benzene ring (Fig. 1). Although the structure difference between CUR and DMC is slight, the chemical characteristics of DMC is more stable $(9,10)$. Previous studies have reported that DMC could inhibit renal and breast cancer cell growth $(11,12)$ and induce $\mathrm{G} 2 / \mathrm{M}$ phase arrest and apoptosis in human glioma U87 cells (13). These studies provide evidence that DMC might be a good substitute for CUR in cancer treatment. However, the effects of DMC on prostate cancer cells still remain unclear. Therefore, the present study was designed to investigate the effects of DMC on proliferation, apoptosis, migration and invasion in cultured human prostate cancer cells. In order to further explore the mechanisms of DMC on cell growth and apoptosis, we investigated the expression of the proliferation cell nuclear antigen (PCNA) and the activation of caspase-3. We also detected the influence of DMC on the activity of matrix metalloproteinases 2 (MMP-2) which is closely related to migration and invasion.

\section{Materials and methods}

Drug preparation. Demethoxycurcumin was purchased from Chengdu Mansite Pharmacetical Co., China ( $>98 \%$ purity), dissolved in dimethylsulfoxide (DMSO) (Sigma, Germany) to $160 \mathrm{mM}$ for storage and diluted in RPMI-1640 medium to different final concentrations in the following experiments.

Cell culture. Human prostate cancer PC-3 cells (Cellular Biology Institute of the Shanghai Academy of Sciences, Shanghai, China) were cultured in RPMI-1640 (Gibco, Invitrogen, USA) medium with $10 \%$ fetal calf serum (FCS, Sijiqing, Hangzhou, China), $100 \mathrm{U} / \mathrm{ml}$ penicillin, $100 \mu \mathrm{g} / \mathrm{ml}$ phytomycin (Invitrogen), and incubated at $37^{\circ} \mathrm{C}$ in humidified atmosphere containing $5 \% \mathrm{CO}_{2}$. Cells were digested with $0.25 \%$ trypsin (Amresco, USA) and subcultured after $90 \%$ confluence. 
MTT assay. PC-3 cells were digested, diluted to $1 \times 10^{4}$ cells per $100 \mu \mathrm{l}$ suspensions, seeded in 96 -well plates ( $100 \mu \mathrm{l}$ per well), and cultured for $24 \mathrm{~h}$. The medium in each well was then replaced with medium containing 5, 10, 20,40,80 and $160 \mu \mathrm{M}$ DMC, $1 \%(\mathrm{v} / \mathrm{v})$ DMSO (vehicle) or $1 \%(\mathrm{v} / \mathrm{v})$ phosphate-buffered saline (PBS) and cultured in the mentioned condition for $12,24,36$ or $48 \mathrm{~h}$. In order to exclude the influence of DMC, supernatant was replaced by fresh medium containing $1 \mathrm{mg} / \mathrm{ml}$ MTT and then incubated for additional $3 \mathrm{~h}$. The medium was then carefully replaced with $150 \mu$ l DMSO, shaken and sufficiently dissolved. Optical density (OD) was recorded at a wavelength of $570 \mathrm{~nm}$. Cell viability in each group was evaluated by OD 570 value. Three independent experiments were performed.

Cell cycle detection. Cell cycle was detected by flow cytometry (FCM). PC-3 cells in each group were digested, and single cell suspensions were centrifuged $\left(500 \mathrm{~g}, 4^{\circ} \mathrm{C}\right.$ for $\left.5 \mathrm{~min}\right)$, washed in ice-cold PBS for 3 times, and then fixed in $70 \%(\mathrm{v} / \mathrm{v})$ precooled ethanol for $24 \mathrm{~h}$. Before detection, the cells were washed 3 times and resuspended in $500 \mu 1$ PBS containing $50 \mathrm{mg} / \mathrm{ml}$ propidium iodide (PI) (Sigma, St. Louis, MO, USA), 0.1\% Triton $\mathrm{X}-100,0.1 \mathrm{mmol} / \mathrm{l} \mathrm{EDTA}(\mathrm{Na})_{2}$ and $50 \mu \mathrm{g} / \mathrm{ml} \mathrm{RNase}$ for $30 \mathrm{~min}$ in the dark. Cells in each group were detected with FACS flow cytometer (Becton-Dickinson, Sunnyvale, CA, USA), and cell cycle distribution was analyzed. The above experiment was repeated 3 times.

Apoptosis analysis. Apoptosis was tested by using an Annexin V/propidium iodide (PI) apoptosis detection kit (Multisciences, China) according to the manufacturer's instructions. In brief, PC-3 cells in each group were trypsinized, centrifuged (500 g, $4^{\circ} \mathrm{C}$ for $5 \mathrm{~min}$ ), and washed with PBS. Next, the cells were resuspended in $500 \mu \mathrm{l}$ of binding buffer, and then $5 \mu \mathrm{l}$ of Annexin $\mathrm{V}$ and $10 \mu 1$ of PI were added in each group. After staining, FCM was performed to detect apoptosis in each group.

Western blot analysis. PC-3 cells were lysed on the ice. Whole cell protein was quantified with BCA assay following the manufacturer's protocol. All of the samples were boiled at $95^{\circ} \mathrm{C}$ for $5 \mathrm{~min}$. Equal protein samples (30-100 $\mu \mathrm{g})$ were loaded onto $8 \%$ SDS-PAGE gels, electrophoresed at $90 \mathrm{~V}$ for $50 \mathrm{~min}$ and then $120 \mathrm{~V}$ for $2 \mathrm{~h}$. Then proteins were transferred to nitrocellulose filters (NC filter; Amersham, Arlington Heights, IL, USA) at $300 \mathrm{~mA}$ for $55 \mathrm{~min}$. Membranes were blocked with $5 \%$ defatted milk for $2 \mathrm{~h}$ at room temperature and then incubated with primary antibodies (anti-PCNA, anti- $\beta$-actin, Santa Cruz Biotechnology, USA; anti-caspase-3, anti-PARP, Cell Signaling Technology, USA) at $4^{\circ} \mathrm{C}$ overnight. The next day, $\mathrm{NC}$ membranes were washed 4 times with TBST (Tris base, $10 \mathrm{mM} ; \mathrm{NaCl}, 150 \mathrm{mM}$; Tween-20, 0.1\%; $\mathrm{pH} 7.4$ ), and incubated in secondary antibodies (anti-rabbit, anti-mouse IgG; Santa Cruz Biotechnology, USA) at room temperature for $1 \mathrm{~h}$. NC membranes were then washed 4 times with TBST, and imaged with LAS-4000 Super CCD Remote Control Science Imaging System (Fujifilm, Japan). Each band was scanned and determined with Quantity One software.

Wound-healing assay. Wound-healing assays were performed to determine cell migration. PC-3 cells were seeded in 6-well plates, incubated in the above mentioned condition. After reaching $100 \%$ confluence, cells were incubated with medium containing<smiles>COc1cc(/C=C/C2=C[CH]OC(/C=C/c3ccc(O)c(OC)c3)=C2)ccc1O</smiles>

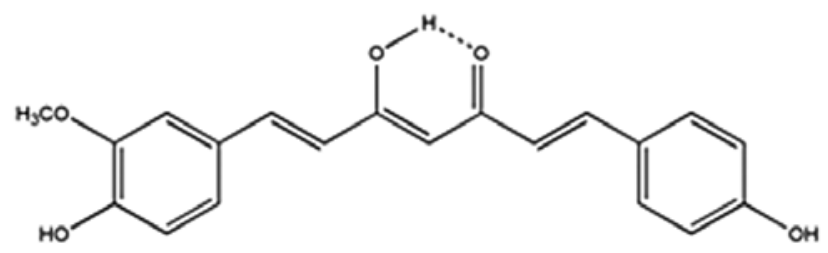

Figure 1. Structure formula of CUR (upper) and DMC (lower).

$1 \%$ FCS for $24 \mathrm{~h}$. Then cells in each well were scratched with a $1 \mathrm{ml}$ sterile pipette tip, washed with PBS 3 times, incubated with medium containing $20,40,80 \mu \mathrm{M}$ or $1 \%$ (v/v) DMSO for $24 \mathrm{~h}$, stained with crystal violet solution and observed with phase contrast microscope. Migration activity was assessed by counting cells migrated to the scratched area in 10 random fields at magnification $\mathrm{x} 40$.

Cell invasion assay. Transwell plates (Corning, USA) with $8.0 \mu \mathrm{m}$ pore size polycarbonate filter membrane were used to investigate the ability of invasion. Matrigel (BD, USA) was added to the filter and dried at $4^{\circ} \mathrm{C}$ overnight to form a thin layer and then incubated in $100 \mu \mathrm{l}$ of PBS at $37^{\circ} \mathrm{C}$ for $1 \mathrm{~h}$. PC-3 cells $\left(1 \times 10^{5}\right)$ were subsequently suspended in $100 \mu 1$ of serum-free RPMI-1640 medium and seeded in the upper chamber of the transwell. The lower chamber was soaked in the same medium with 5\% of FCS. After $12 \mathrm{~h}$, the cells on the upper chamber were removed with a cotton swab. Invasive cells on the lower surface of the filter were then stained with crystal violet and counted in 10 random fields at magnification $\mathrm{x} 400$.

Gelatin zymography analysis. MMP-2 activity was determined by gelatin zymography assay. Briefly, equal volume of conditioned medium in each group was loaded onto 8\% SDS-PAGE containing $0.1 \%$ gelatin. Electrophoresis was performed at $4{ }^{\circ} \mathrm{C}$ condition, and run at $120 \mathrm{~V}$ for $2 \mathrm{~h}$. The gel was washed in $2.5 \%$ (v/v) Triton X-100 3 times and incubated with reaction buffer (Tris base, $50 \mathrm{mM} ; \mathrm{NaCl}, 50 \mathrm{mM} ; \mathrm{CaCl}_{2}, 10 \mathrm{mM}, \mathrm{pH}$ 7.6) at $37^{\circ} \mathrm{C}$ overnight. The gel was stained with Coomassie Brilliant Blue solution, and then scanned and analyzed with Quantity One software.

Statistical analysis. SPSS 13.0 software was used in all the statistical analysis. Values were expressed as mean $\pm \mathrm{SD}$. One-way ANOVA or Student's t-test were performed. $\mathrm{P}<0.05$ was considered as statistically significant.

\section{Results}

DMC inhibits $P C-3$ cell proliferation. In order to investigate whether DMC inhibits PC-3 growth, we first exposed PC-3 cells to various concentrations of DMC for $12,24,36$ or $48 \mathrm{~h}$ respectively, and detected cell viability with MTT assay. As shown in 

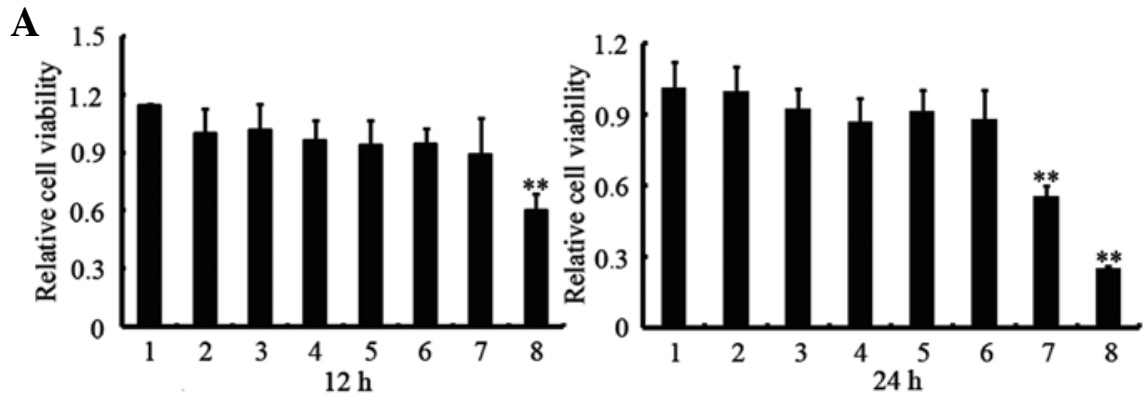

B
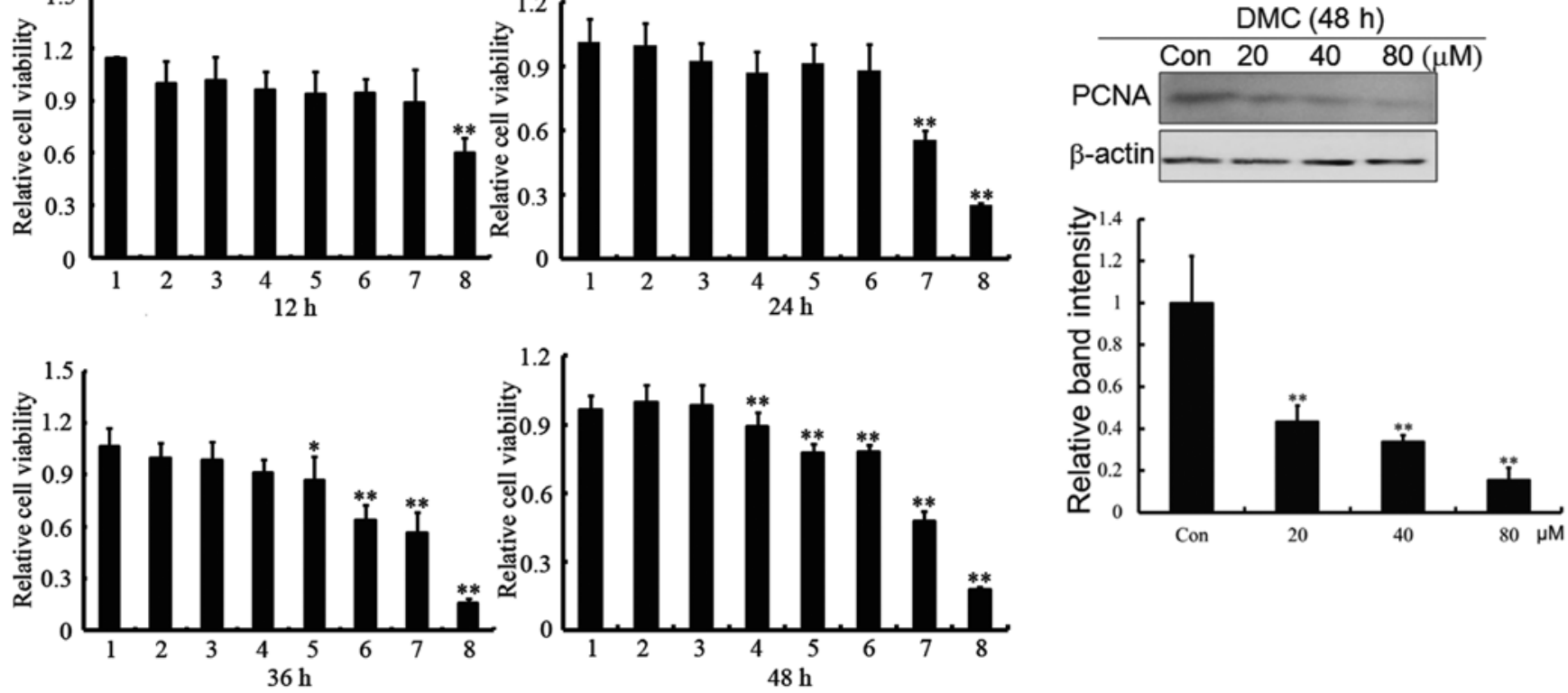

C
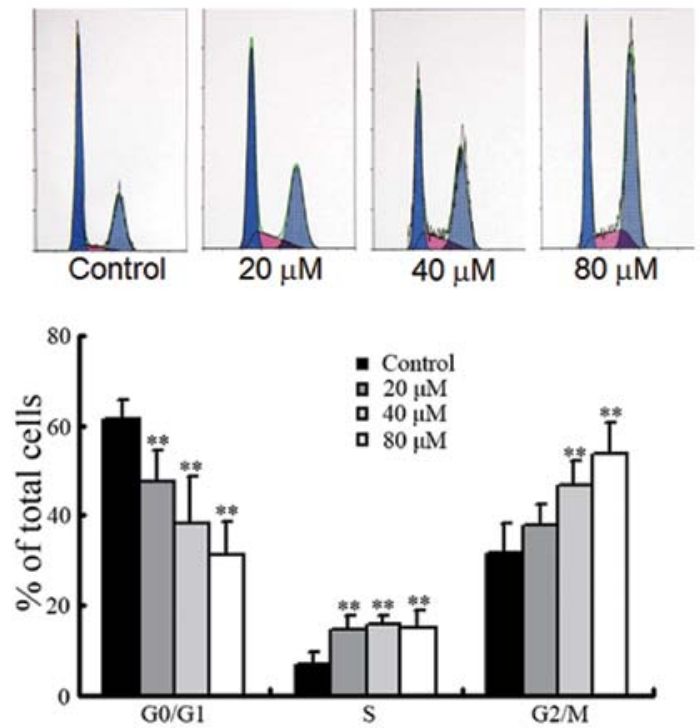

D

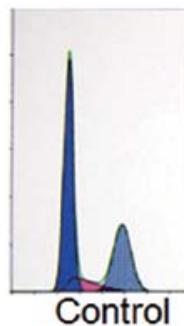

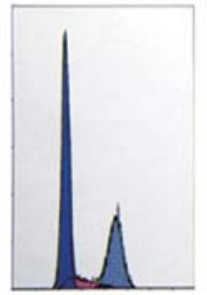

$12 \mathrm{~h}$

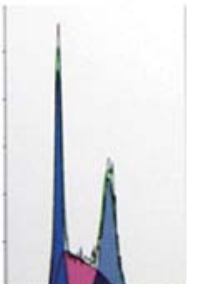

$24 \mathrm{~h}$

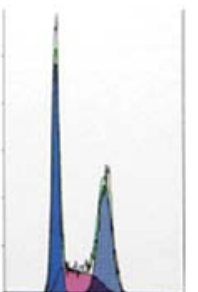

$36 \mathrm{~h}$
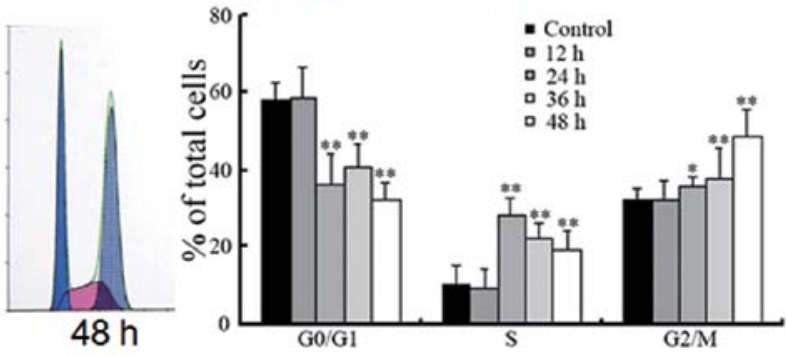

Figure 2. Effects of DMC on proliferation of PC-3 cells. (A) Viability was measured by MTT assay. PC-3 cells were treated with $1 \%$ PBS (lane 1), $1 \%$ DMSO (lane 2) or 5, 10, 20, 40, 80 and $160 \mu \mathrm{M}$ DMC (lanes 3-8) for the indicated time. (B) The expression of PCNA was detected by western blotting. The cell cycle distribution of PC-3 cells for analyzing (C) dose- and (D) time-effects were detected by FCM. Three independent experiments were performed and DMSO treated group was regarded as control. Values are expressed as mean $\pm \mathrm{SD}$. ${ }^{*} \mathrm{P}<0.05$ and ${ }^{* *} \mathrm{P}<0.01$, compared to the control.

Fig. 2A, PC-3 cell viability in DMC groups was significantly reduced compared with vehicle control $(\mathrm{P}<0.05)$. The $\mathrm{IC}_{50}$ values in 12, 24, 36 and $48 \mathrm{~h}$ were 483.8, 111.6, 65.3, 64.9 $\mu \mathrm{M}$, respectively. The PCNA expression as a proliferation marker was also reduced in DMC treated cells compared with DMSO group (Fig. 2B). These results indicated that DMC suppressed PC-3 cell proliferation in both dose- and time-dependent manner.

DMC induces G2/M phase cell cycle arrest to PC-3 cells. To further analyze the mechanism of DMC on proliferation inhibition in PC-3 cells, we first treated PC-3 cells with DMC at final concentrations of 20,40 and $80 \mu \mathrm{M}$ for $48 \mathrm{~h}$. Then we treated PC-3 cells with DMC ( $40 \mu \mathrm{M}$ ) for $12,24,36$ and $48 \mathrm{~h}$ and cell cycle was determined by FCM. Our results indicated that the percentage of G2/M phase cells in DMC treated groups was significantly increased compared with DMSO group (Fig. 2C), while the percentage of $\mathrm{G} 2 / \mathrm{M}$ phase cells was also gradually increased in 24, 36 and $48 \mathrm{~h}$ groups (Fig. 2D). These results indicated that the arrested PC-3 cell cycle might contribute to the proliferation inhibition effect of DMC.

DMC induces PC-3 cell apoptosis. We next investigated whether $\mathrm{DMC}$ has the potency of apoptosis induction. We incubated PC-3 cells in medium containing 20, 40 and $80 \mu \mathrm{M}$ DMC for the indicated time (Fig. 3A and B), and then cell apoptotic rate was detected by FCM. Our results demonstrated that in DMC treated groups ( 40 and $80 \mu \mathrm{M}$ ), the apoptotic rate was increased by 2- to 4-fold compared with control (Fig. 3A). Besides, cell apoptosis level was markedly elevated when DMC exposure time reached $48 \mathrm{~h}$ (Fig. 3B). These results indicated that DMC could induce 
A

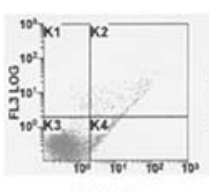

Control

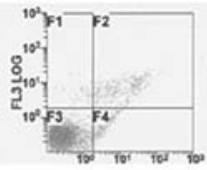

$20 \mu \mathrm{M}$

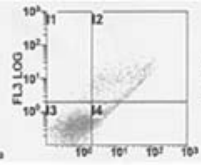

$40 \mu \mathrm{M}$

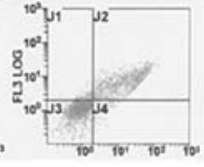

$80 \mu \mathrm{M}$

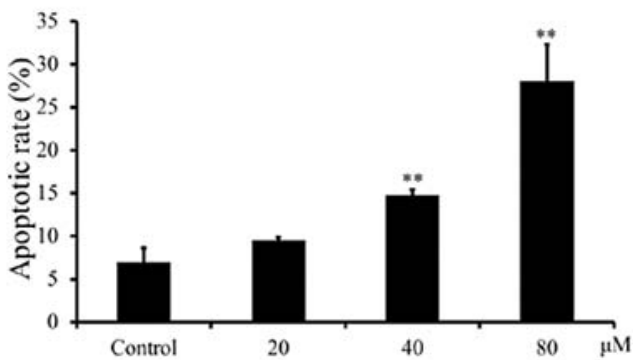

B

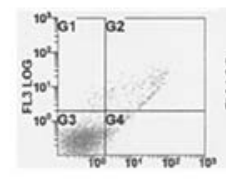

Control

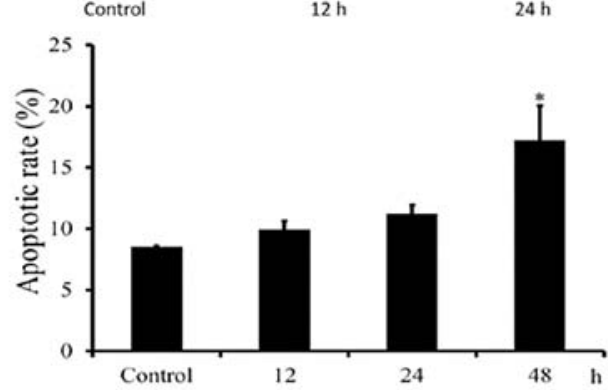

C

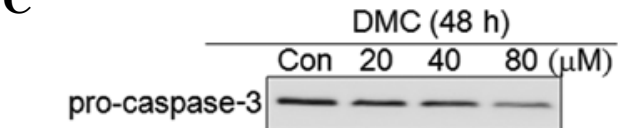

Figure 3. Effects of DMC on apoptosis of PC-3 cells. Both (A) dose- and (B) time-effects on apoptosis induced by DMC were analyzed by FCM. (C) The effects of caspase-3 activation and cleaved PARP were detected by Western blotting. Representative results are from three independent experiments and DMSO treated group was regarded as control. Values are expressed as mean \pm SD. ${ }^{*} \mathrm{P}<0.05$ and ${ }^{* *} \mathrm{P}<0.01$, compared to the control group.

PC-3 cell apoptosis in dose- and time-dependent manner. In CUR induced apoptotic cells, caspase-3 is eventually activated $(14,15)$. Therefore, we supposed that caspase- 3 activation also plays an important role in DMC induced apoptosis. We detected cleaved caspase-3 and its substrate poly ADP-ribose polymerase (PARP) by western blotting. Our result indicated that the cleaved caspase-3 protein was significantly increased in DMC treated PC-3 cells compared with the control group. In contrast, the procaspase- 3 was reduced after DMC treatment. Consistent with caspase-3, the cleaved PARP protein was also increased in DMC treated groups (Fig. 3C). These results verified that DMC could
A

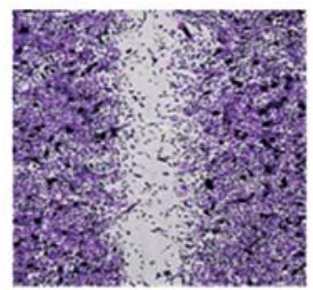

Control

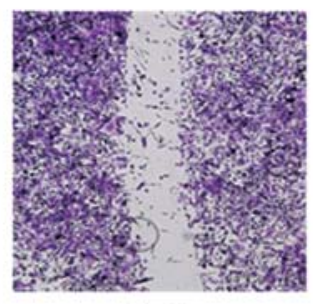

$40 \mu \mathrm{M}$

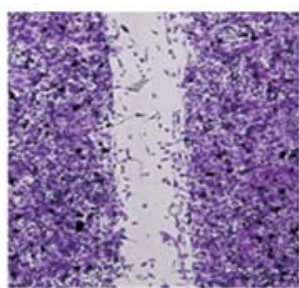

$20 \mu \mathrm{M}$

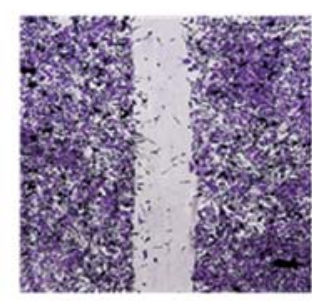

$80 \mu \mathrm{M}$

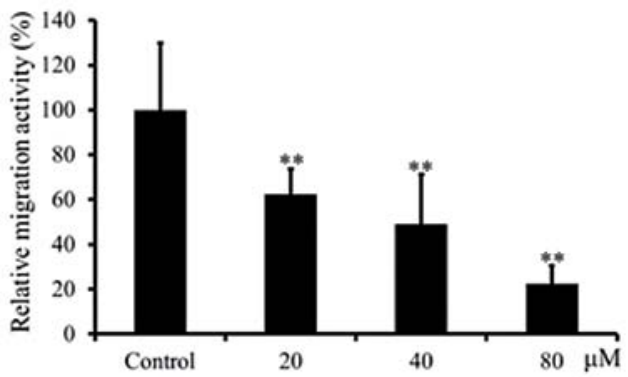

B

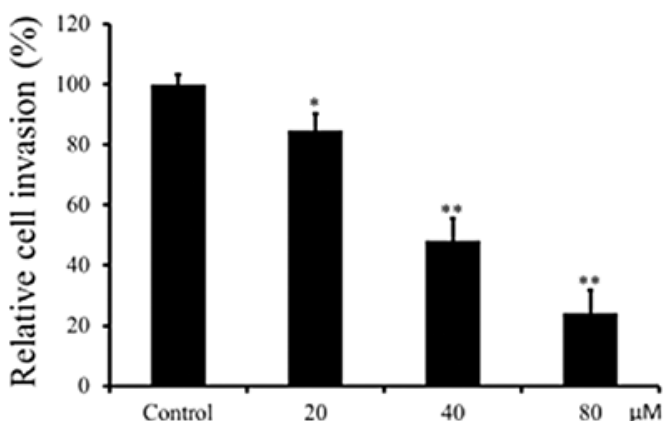

C
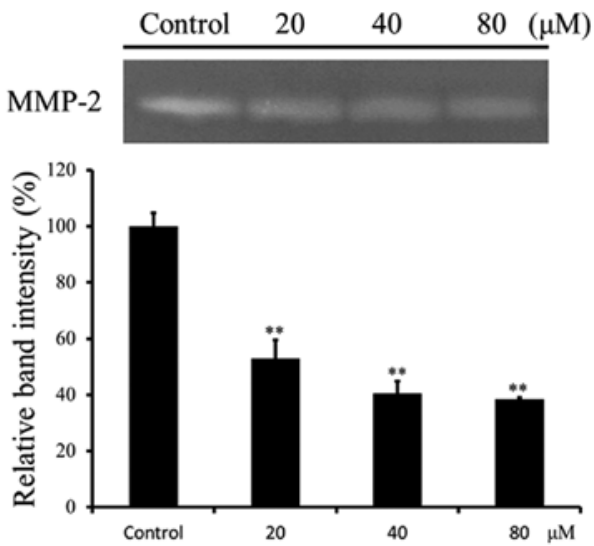

Figure 4. Effects of DMC on migration and invasion of PC-3 cells. (A) Cell migration was determined by wound-healing assay. $\mathrm{PC}-3$ cells were treated with the indicated concentrations of DMC. The migrating cells in the scratched area were counted in 10 random fields (x40). (B) Transwell assay was performed to analyze cell invasion. Invasive cells on the lower surface of the filter were counted in 10 random fields at magnification x400. (C) MMP-2 activity was detected by gelatin zymography. Three independent experiments were performed and DMSO treated group was regarded as control. Values are expressed as mean \pm SD. ${ }^{*} \mathrm{P}<0.05$ and ${ }^{* *} \mathrm{P}<0.01$, compared to the control group. 
induce apoptosis in PC-3 cells and the activation of caspase-3 might be involved in this process.

DMC inhibits PC-3 cell migration and invasion. Migration and invasion are well known as the pathologic basis of metastasis of malignant cancer. We also investigated whether DMC could inhibit PC-3 cells migration and invasion. Results from woundhealing assays demonstrated that in DMC treated groups (20, 40 and $80 \mu \mathrm{M})$ the migrating cells in the scratched area were significantly reduced to $62.3,49.2$ and $22.6 \%$, respectively, compared with the control group (Fig. 4A). Transwell assay results suggested that the invasion was reduced to 84.7, 48.2 and $24.2 \%$ when treated with DMC (20,40 and $80 \mu \mathrm{M}$, respectively) compared with control (Fig. 4B). MMP-2 is closely related to migration in many cancers (16-18). Therefore, we next detected whether the activity of MMP-2 is affected by DMC treatment. The results in gelatin zymography indicated that the MMP-2 activity was inhibited by DMC compared with the control group (Fig. 4C). These results indicated that DMC could inhibit MMP-2 activity and this effect might contribute to the inhibition of migration and invasion in PC-3 cells.

\section{Discussion}

Several members of curcuminoids have potent anti-tumor effects (2-6). Simon et al reported that DMC showed the highest anti-tumor bioactivity in three different curcuminoids to breast cancer cells (19). DMC also induced G2/M phase arrest and apoptosis in human glioma U87 cells (13). Consistent with these studies, we observed the reduced proliferation and G2/M phase arrest in DMC treated PC-3 cells. Although it was not evaluated by us, the reduced proliferation might attribute to the DMC molecular binding with Bcl-2 and the subsequent G2 checkpoint arrest that has been already reported (13). Furthermore, our results revealed that DMC strongly induced PC-3 cells apoptosis. In CUR-induced apoptosis, caspase-3 is activated $(14,15)$. The cleaved caspase- 3 protein triggers a range of biochemical reactions eventually leading to apoptosis. In PC-3 cells, the activated caspase-3 was significantly enhanced by DMC, especially in the $80 \mu \mathrm{M}$ group. Our results indicated that caspase- 3 might partially be involved in apoptosis of DMC treated PC-3 cells.

Migration and invasion are two basic stages for metastasis. Previous studies have confirmed that curcuminoids inhibit cancer cells migration and invasion (12,20-22). In our study, DMC also showed potent suppression effects on migration and invasion in PC-3 cells. Many cancer cells secrete a series of proteinases, such as MMPs, serine protease, cysteine protease and urokinase plasminogen activator system (23). These proteinases gradually degrade the extracellular matrix (ECM) and promote migration and invasion. The basement membrane plays an important role in limiting cancer cell metastasis. However, most cancer cells secrete high activated gelatinases, such as MMP-2 and -9, to degrade the basement membrane. In previous case-control studies, MMP-2 and -9 are closely related to various malignant tumors (16-18,24-29). These studies provide evidence that the expression of MMPs is closely associated with prostate cancer migration and invasion. We observed that DMC factually inhibited PC-3 cells migration and invasion. Furthermore, the MMP-2 activity was also suppressed in a dose-dependent manner. These results indicated that the effects of DMC in inhibiting migration and invasion might partially be via suppressing MMP-2 secretion and activation.

The present study provides evidence that DMC significantly inhibits PC-3 cells proliferation, migration, invasion, as well as inducing prostate cancer cells apoptosis. CUR is unstable in physiological environment and can be rapidly catabolized by the 'first pass effect' in the liver when it is taken orally $(7,8)$. In contrast, DMC is more stable and its half-life period is significantly prolonged compared with CUR $(9,10)$. These studies and our research support that DMC is a curcuminoid candidate which is more likely to be used clinically. PC-3 cell line used in this research is derived from hormonal refractory prostate cancer (HRPC) (30). Therefore, one of the limits of our research is that we did not investigate the effects in hormonal sensitive and other hormonal refractory prostate cancer derived cell lines. For most hormonal sensitive prostate cancer cases, endocrine therapy is effective. In contrast, for HRPC patients, endocrine therapy is always disappointing. Therefore, we considered that the study of DMC treatment in HRPC patients is much more meaningful. In vitro study is another limit of this research. Despite the improved metabolic stability and anticancer activity for DMC compared with CUR (10), it remains to be disclosed whether DMC still exhibits anti-prostate cancer effects in vivo.

In conclusion, DMC has potent anti-tumor effects that might be used in treating and preventing prostate cancer.

\section{Acknowledgements}

This study was supported by grants from the Hebei Provincial Program for the Subjects with High Scholarship and Creative Research Potential. We thank Dr Wei Qiu (Peking University First Hospital) and Dr Ming Su (Peking Union Medical College) for their advice on cell culture and gelatin zymography. We also thank Dr Lihua Liu (The Fourth Hospital of Hebei Medical University) for her kind help on FCM and other techniques.

\section{References}

1. McCann SE, Ambrosone CB, Moysich KB, Brasure J, Marshall JR, Freudenheim JL, Wilkinson GS and Graham S: Intakes of selected nutrients, foods, and phytochemicals and prostate cancer risk in western New York. Nutr Cancer 53: 33-41, 2005

2. Teiten MH, Gaascht F, Cronauer M, Henry E, Dicato M and Diederich M: Anti-proliferative potential of curcumin in androgendependent prostate cancer cells occurs through modulation of the Wingless signaling pathway. Int J Oncol 38: 603-611, 2011.

3. Dorai T, Gehani N and Katz A: Therapeutic potential of curcumin in human prostate cancer - I. Curcumin induces apoptosis in both androgen-dependent and androgen-independent prostate cancer cells. Prostate Cancer Prostatic Dis 3: 84-93, 2000.

4. Deeb D, Xu YX, Jiang H, Gao X, Janakiraman N, Chapman RA and Gautam SC: Curcumin (diferuloyl-methane) enhances tumor necrosis factor-related apoptosis-inducing ligand-induced apoptosis in LNCaP prostate cancer cells. Mol Cancer Ther 2: 95-103, 2003.

5. Mehta K, Pantazis P, McQueen T and Aggarwal BB: Antiproliferative effect of curcumin (diferuloylmethane) against human breast tumor cell lines. Anticancer Drugs 8: 470-481, 1997.

6. Lee YK, Park SY, Kim YM and Park OJ: Regulatory effect of the AMPK-COX-2 signaling pathway in curcumin-induced apoptosis in HT-29 colon cancer cells. Ann NY Acad Sci 1171: 489-494, 2009.

7. Ireson C, Orr S, Jones DJ, Verschoyle R, Lim CK, Luo JL, Howells L, Plummer S, Jukes R, Williams M, Steward WP and Gescher A: Characterization of metabolites of the chemopreventive agent curcumin in human and rat hepatocytes and in the rat in vivo, and evaluation of their ability to inhibit phorbol ester-induced prostaglandin E2 production. Cancer Res 61: 1058-1064, 2001. 
8. Ireson CR, Jones DJ, Orr S, Coughtrie MW, Boocock DJ, Williams ML, Farmer PB, Steward WP and Gescher AJ: Metabolism of the cancer chemopreventive agent curcumin in human and rat intestine. Cancer Epidemiol Biomarkers Prev 11: 105-111, 2002.

9. Han G, Cui JJ, Bi R, Zhao LL and Zhang WG: Study on stability of curcumine, demethoxycurcumin and bisdemethoxycurcumin Zhongguo Zhong Yao Za Zhi 33: 2611-2614, 2008 (In Chinese).

10. Tamvakopoulos C, Dimas K, Sofianos ZD, Hatziantoniou S, Han Z, Liu ZL, Wyche JH and Pantazis P: Metabolism and anticancer activity of the curcumin analogue, dimethoxycurcumin. Clin Cancer Res 13: 1269-1277, 2007.

11. Lee JW, Hong HM, Kwon DD, Pae HO and Jeong HJ: Dimethoxycurcumin, a structural analogue of curcumin, induces apoptosis in human renal carcinoma caki cells through the production of reactive oxygen species, the release of cytochrome $\mathrm{C}$, and the activation of caspase-3. Korean J Urol 51: 870-878, 2010.

12. Yodkeeree S, Ampasavate C, Sung B, Aggarwal BB and Limtrakul P: Demethoxycurcumin suppresses migration and invasion of MDA-MB-231 human breast cancer cell line. Eur J Pharmacol 627: 8-15, 2010.

13. Luthra PM, Kumar R and Prakash A: Demethoxycurcumin induces Bcl-2 mediated G2/M arrest and apoptosis in human glioma U87 cells. Biochem Biophys Res Commun 384: 420-425, 2009.

14. Thayyullathil F, Chathoth S, Hago A, Patel M and Galadari S Rapid reactive oxygen species (ROS) generation induced by curcumin leads to caspase-dependent and -independent apoptosis in L929 cells. Free Radic Biol Med 45: 1403-1412, 2008.

15. Su CC, Lin JG, Li TM, Chung JG, Yang JS, Ip SW, Lin WC and Chen GW: Curcumin-induced apoptosis of human colon cancer colo 205 cells through the production of ROS, $\mathrm{Ca}^{2+}$ and the activation of caspase-3. Anticancer Res 26: 4379-4389, 2006.

16. Stearns M and Stearns ME: Evidence for increased activated metalloproteinase 2 (MMP-2a) expression associated with human prostate cancer progression. Oncol Res 8: 69-75, 1996.

17. Stearns ME and Stearns M: Immunohistochemical studies of activated matrix metalloproteinase-2 (MMP-2a)expression in human prostate cancer. Oncol Res 8: 63-67, 1996.

18. Montironi R, Lucarini G, Castaldini C, Galluzzi CM, Biagini G and Fabris G: Immunohistochemical evaluation of type IV collagenase (72-kd metalloproteinase) in prostatic intraepithelial neoplasia. Anticancer Res 16: 2057-2062, 1996.

19. Simon A, Allais DP, Duroux JL, Basly JP, Durand-Fontanier S and Delage C: Inhibitory effect of curcuminoids on MCF-7 cell proliferation and structure-activity relationships. Cancer Lett 129: 111-116, 1998.
20. Yodkeeree S, Chaiwangyen W, Garbisa S and Limtrakul P: Curcumin, demethoxycurcumin and bisdemethoxycurcumin differentially inhibit cancer cell invasion through the down-regulation of MMPs and uPA. J Nutr Biochem 20: 87-95, 2009.

21. Lin SS, Lai KC, Hsu SC, Yang JS, Kuo CL, Lin JP, Ma YS, Wu CC and Chung JG: Curcumin inhibits the migration and invasion of human A549 lung cancer cells through the inhibition of matrix metalloproteinase-2 and -9 and vascular endothelial growth factor (VEGF). Cancer Lett 285: 127-133, 2009.

22. Chen HW, Lee JY, Huang JY, Wang CC, Chen WJ, Su SF, Huang CW, Ho CC, Chen JJ, Tsai MF, Yu SL and Yang PC: Curcumin inhibits lung cancer cell invasion and metastasis through the tumor suppressor HLJ1. Cancer Res 68: 7428-7438, 2008.

23. Liotta LA, Tryggvason K, Garbisa S, Hart I, Foltz CM and Shafie S: Metastatic potential correlates with enzymatic degradation of basement membrane collagen. Nature 284: 67-68, 1980.

24. Kawano N, Osawa H, Ito T, Nagashima Y, Hirahara F, Inayama Y, Nakatani Y, Kimura S, Kitajima H, Koshikawa N, Miyazaki K and Kitamura $\mathrm{H}$ : Expression of gelatinase A, tissue inhibitor of metalloproteinases-2, matrilysin, and trypsin(ogen) in lung neoplasms: an immunohistochemical study. Hum Pathol 28: 613-622, 1997.

25. Fishman DA, Bafetti LM and Stack MS: Membrane-type matrix metalloproteinase expression and matrix metalloproteinase-2 activation in primary human ovarian epithelial carcinoma cells. Invasion Metastasis 16: 150-159, 1996.

26. Young TN, Rodriguez GC, Rinehart AR, Bast RC Jr, Pizzo SV and Stack MS: Characterization of gelatinases linked to extracellular matrix invasion in ovarian adenocarcinoma: purification of matrix metalloproteinase 2. Gynecol Oncol 62: 89-99, 1996.

27. Bramhall SR, Neoptolemos JP, Stamp GW and Lemoine NR: Imbalance of expression of matrix metalloproteinases (MMPs) and tissue inhibitors of the matrix metalloproteinases (TIMPs) in human pancreatic carcinoma. J Pathol 182: 347-355, 1997.

28. Murray GI, Duncan ME, O'Neil P, McKay JA, Melvin WT and Fothergill JE: Matrix metalloproteinase-1 is associated with poor prognosis in oesophageal cancer. J Pathol 185: 256-261, 1998.

29. Murray GI, Duncan ME, O'Neil P, Melvin WT and Fothergill JE: Matrix metalloproteinase-1 is associated with poor prognosis in colorectal cancer. Nat Med 2: 461-462, 1996.

30. Kaighn GI, Narayan KS, Ohnuki Y, Lechner JF and Jones LW: Establishment and characterization of a human prostatic carcinoma cell line (PC-3). Invest Urol 17: 16-23, 1979. 